\title{
Kırık Fragmanı Eklem İçinde Olan Medial Epikondil Kırığıyla Birlikte İhmal Edilmiş Pediatrik Dirsek Çıkığı: Olgu Sunumu
}

\author{
Neglected Elbow Dislocation with Medial Epicondyle Fracture That Was Entrapped \\ into the Elbow Joint: A Case Report \\ Mehmet Serhan ER ${ }^{1}$, Mehmet YÜCEHAN ${ }^{2}$, Mehmet EROĞLU², Levent ALTINEL ${ }^{1}$ \\ ${ }^{1}$ Akdeniz Üniversitesi Tıp Fakültesi, Ortopedi ve Travmatoloji AD, Antalya \\ ${ }^{2}$ Afyon Kocatepe Üniversitesi Tıp Fakültesi, Ortopedi ve Travmatoloji AD, Afyonkarahisar
}

\begin{abstract}
öz
Travmatik dirsek çıkığı çocuklarda nadirdir ve zamanında tanı konulduğunda tedavi etmek genellikle kolaydır. Ancak tanı, yaralanmadan 3 hafta ve sonrasında tanı konulmuş ve dirsek çıkığına medial epikondil kırığı da eşlik ediyor ise tedavi daha karmaşık hale gelebilir. Biz burada medial epikondil kırığının eşlik ettiği ve kırık fragmanının eklem içinde olduğu, tedavisi gecikmiş dirsek çıkığı olan 13 yaşındaki bir hastamızı sunmaktayız. Dirsek çıkığı ve medial epikondil kırığı açık redükte edildi ve kırık fragman Kirschner telleri ile tespit edildi. Hasta fizik tedavi programı ile takip edildi. Sonuçta kabul edilebilir sınırlarda dirsek fonksiyonu elde edildi.
\end{abstract}

Anahtar Kelimeler: İhmal edilmiş; dirsek çıkığı; pediatrik

\begin{abstract}
Traumatic dislocation of the elbow is rare in children and it's generally easy to treat when diagnosed in time. However, if it is diagnosed three weeks or more after the injury and the dislocation is complicated with the avulsion fracture of the medial epicondyle, treatment is more difficult. We report a 13 year-old patient with an unusual case of neglected elbow dislocation with medial epicondyle fracture that was entrapped into the elbow joint. Open reduction of elbow dislocation and internal fixation of medial epicondyle fracture was performed. After physical therapy programme, eventually elbow function was restored to acceptable ranges.
\end{abstract}

Keywords: Neglected; elbow dislocation; pediatric 


\section{Giriş̧}

Çocuklarda travmatik dirsek çıkığı tüm çocuk dirsek yaralanmalarının \%3-6'sını oluşturur ve genellikle erken tanı konulduğunda tedavisi kolaydır (1). Ancak tanı 3 hafta veya daha uzun süre gecikme ile konulmuş ve dirsek çıkığına medial epikondil kırığı da eşlik ediyor ise yumuşak doku kontraktürüne bağlı olarak tedavi daha karmaşık hale gelebilir (2). Buna ilaveten nedbe dokusu, yeni kemik oluşumları ve kırık kemik fragmanının eklem içerisinde sıkışması kapalı redüksiyonu engelleyebilir. Bu gibi yaralanmalar genellikle sınıkçı müdahalelerinin yaygın olduğu gelişmemiş ülkelerde görülmektedir.

Biz burada medial epikondil kırığının eşlik ettiği ve kırık fragmanının eklem içinde olduğu tedavisi gecikmiş dirsek çıkığı olan bir hastamızı sunmayı amaçladık.

\section{OLGU SUNUMU}

Onüç yaşında bayan hasta, 24 gün önce sol dirseği üzerine düşme sonucu oluşan yaralanma nedeni ile polikliniğimize başvurdu. Hikâyesinden ilk müdahalesinin sınıkçı tarafından yapıldığı ve bize gelinceye kadar herhangi bir tıbbi tedavi görmediği öğrenildi. Muayenesinde dirsek eklem hareket açıklığı (EHA) 100-300 olarak tespit edildi. Dirsek ön-arka, yan grafilerinde ve bilgisayarlı tomografide (Şekil IA-IB) kırık fragmanı eklem içinde olan medial epikondil kırığıyla birlikte posterolateral dirsek çıkığı tespit

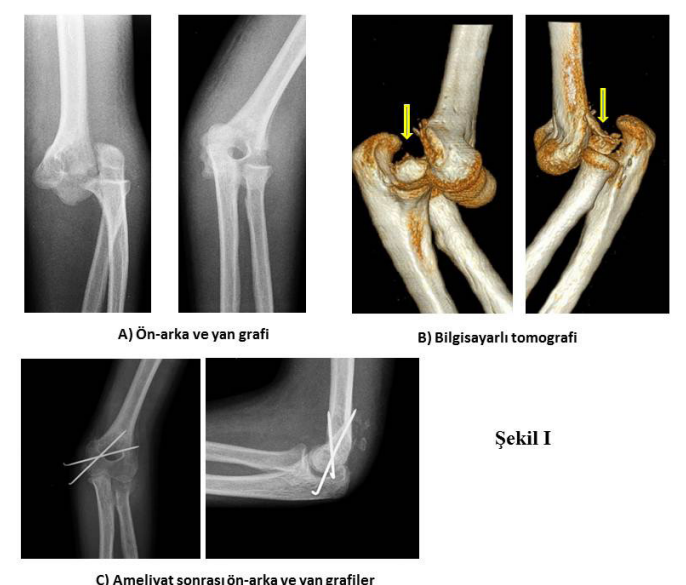

Şekil I: A) Ameliyat öncesi ön-arka ve yan grafiler, B) Ameliyat öncesi üç boyutlu bilgisayarlı tomografi görüntüsü, C) Ameliyat sonrası ön-arka ve yan grafiler edildi. Genel anestezi altında, eklem aralığına sıkışan medial epikondil kırık fragmanı eklem aralığından çıkartılarak anatomik olarak redükte edildi ve 2 adet Kirschner teli (K-teli) ile tespit edildi (Şekil IC). Ardından dirsek eklemi nazikçe redükte edildi. İntraoperatif muayenede dirsek EHA normal olarak değerlendirildi. Triseps kası Speed V-Y muskuloplasti tekniği ile uzatıldı. Postoperatif uzun kol atel uygulandı.

Ameliyattan 2 hafta sonra aktif dirsek hareketlerine fizik tedavi uzmanı gözetiminde başlandı. Postoperatif 6. haftada K-teli çıkarıldı. Ameliyattan 2 ay sonra yapılan fizik muayenede EHA 500-1300 arasındaydı (800 fleksiyon arkı) ve ön kol rotasyonu kısıtlı değildi. Bunun üzerine genel anestezi altında dirsek eklem manipülasyonu yapılarak dirsek eklemi fleksiyon kontraktürü 300 'ye düşürüldü. Hastanın halen 500-1500 dirsek hareket açıklığı mevcuttur ve günlük aktivitelerini sorunsuz yapabilmektedir.

\section{TARTIŞMA}

Çoğu cerrah 3 haftaya kadar olan dirsek çıkıklarında kapalı redüksiyon önermektedir. Yaralanmanın üzerinden 3 haftadan fazla bir süre geçmişse yumuşak doku kontraktürüne bağlı olarak kapalı redüksiyon daha zor hale gelir. Buna rağmen manipülasyon denenirse eklem yüzeyi hasarı veya kemik kırığı oluşabilir. Çoğu otorite 3 aya kadar dirsek redüksiyonu için açık redüksiyon önermektedir $(3,4)$. Günlük hayattaki çoğu aktivite 1000 fleksiyon arkı ve 1000 supinasyon - pronasyon arkı ile yapılabilmektedir. Bizim hastamızda da hareket açıklığı bu düzeyde olup günlük aktivitelerini yapabilmektedir.

Gecikmiş dirsek kırıklı çıkıklarında açık redüksiyonla birlikte $\mathrm{V}$-Y muskuloplasti ve sonrasında gözetim altında yapılan fizik tedavi programı ile dirsek fonksiyonları kabul edilebilir düzeylere gelmektedir.

\section{KAYNAKLAR}

1. Wilkins KE. Fractures and dislocations of the elbow region. In: Rockwood CA, Wilkins KE, King RE (Editors). Fractures in children. Philadelphia: Lippincott-Raven, 1996:653-887. 
2. Saraf SK, Tuli SM. Concomitant medial condyle fracture of the humerus in a childhood posterolateral dislocation of the elbow. J Orthop Trauma 1989;3(4):352-4.

3. Fowles JV, Kassab MT, Douik M. Untreated posterior dislocation of the elbow in children. J Bone Joint Surg Am 1984;66(6):921-6.

4. Fowles JV, Slimane N, Kassab MT. Elbow dislocation with avulsion of the medial humeral epicondyle. J Bone Joint Surg Br 1990;72(1):102-4. 